\title{
Covid-19: A Reason behind Digital Education in Pakistan
}

\author{
Madieha Akram \\ Assistant Professor, \\ School of Sociology, Minhaj University Lahore, \\ Hamdard Chowk, Township, \\ Lahore, Pakistan \\ Faiza Anjum \\ Assistant Professor, \\ Department of Humanities and Social Sciences, \\ National Textile University, \\ Sheikhupura Road, Faisalabad 37610, Pakistan \\ Corresponding Author

\section{Zahira Batool} \\ Professor, Department of Sociology, \\ Government College University, \\ Allama Iqbal Road, Faisalabad, Pakistan
}

DOI: https://doi.org/1o.36941/mjss-2020-0037

\section{Abstract}

Covid-19 is new virus that is spreading rapidly in all over the world. It is a communicable disease. World Health Organization announced social distancing to control the spread of that virus. All institutions are closed in Pakistan. Education was also effecting with this shutdown. A number of educational institutions have started digital education. Education is an important institution of socialization. Traditional education is not possible because of Covid-19. Digital education is taking its place according to the situation. An online survey was conducted to understand the acceptance level of online education in Lahore, Pakistan. A number of 240 students who were attending online classes solved the questionnaire. A software "Statistical package of social sciences" was used to see the distribution of the respondents. A statistical analysis showed that majority of the respondents is accepting online education according to the condition. It is suggested that Government should spread awareness regarding online education to make it more successful because it is the need of the time.

Keywords: Covid-19; Digital education; Students; Online classes; Pakistan

\section{Introduction}

Education is very important. No one can deny its value because it is an acceptable phenomenon in all over the world. It changes the lives of the people. An educated person can survive in hard days of life. Education polishes the behavior of the people. The supportive leadership is very important to 
highlight the value of education (Johansson, et al., 2010). Parents and teachers can lead a child towards better life. This better life can be achieved through education and skills. An educated person can use skills to achieve success in every part of life. Education is not only a piece of paper but it is a personality that shows by talk, walk, etiquettes, manners and thoughts. An educated person is a complete human being. We can't say every educated person is a best one but we can say that every person who has education and practically showing that education through personality is a best one.

A novel coronavirus (2019-nCoV) pandemic is affecting people all over the world. Institutions are closed. Total situation is changed. It is spreading from one person to another. So the whole world is keeping distance from one another (WHO, 2019; Bai et al., 2020). In this situation when all social activities are closed. Educational institutions are closed as well. Digital education is taking place to save the time of the students. Online education is spreading everywhere.

Developed countries have higher level of education like Finland, Norway, and Poland etc. Pakistan is also trying to increase the level of education. In this Covid-19 pandemic, Pakistan has adopted online education model. While online education was not common in Pakistan before Covid19. In Pakistan, HEC (2020) allowed educational institutions to continue teaching and learning through different distance learning approaches. This survey was conducted to know the level of acceptance of online classes in Pakistan.

\section{Objectives}

1- To find out the level of acceptance of online classes

2- To highlight the factors affecting digital education

3- To give some suggestions to make online classes more effective

\section{Review of Literature}

A lot of studies are supporting the statement that education plays a great role in the development of the people. Parental class and education also effects on children's interest in education (Bukodi and Goldthorpe, 2013). Those children who are staying at home in the Covid-19 pandemic and learning through distance educational programs are getting more attention from their parents because parents are observing their child's activities all the time. In this situation educated parents are playing more helpful role than uneducated parents. The socio-economic status of the family also has importance in attainment of education (Ichou, 2014). In developing countries like Pakistan a number of families don't have modern digital technology (Laptop, Mobile, Television and Internet) to provide their children for online education.

Parental aspiration is another important factor in child's education (Spera et al., 2009). Home based learning environment is possible only when parents know the importance of education. Rud et al., (2014) stated that parental behavior effects child's behavior. Children learn from their parents their values, standards, choices, skills, etc. Moller and Soles (2001) highlighted the importance of digital education in this modern era. The virtual classroom is an alternative way to continue education even in Covid-19 pandemic. The digital learning system is totally different from traditional learning system. Another research (Palloff and Pratt, 1999) shows that those students who are introverted have more chances to be successful in distance learning educational system than those who are extroverted. The reason behind it is that introverted personality likes to stay inside and don't want to participate in gatherings.

Distance education is better than traditional education. For this purpose a number of software are in market (Grant, 2008). Online education is a modern way to teach (Shen et al., 2001). There are some merits as well as demerits of online education. Students can't interact wither their teachers directly as they used to do in traditional education system same as they are unable to meet their peers as they met in old educational set-up (Galusha, 1998). 


\section{Methodology}

A well-structured questionnaire was designed to collect the information from students (aged 18-30 years). A questionnaire was circulated among students through social media because of social distancing situation. In the time of Covid-19 all institutions in Punjab were closed and online classes were going on so data was collected online. A number of 240 students from Lahore, Punjab, Pakistan solved that questionnaire. These students were attending online classes. Questionnaire was consisted upon 10 questions. Univariate analysis was done through statistical package for social sciences (SPSS).

\section{Results}

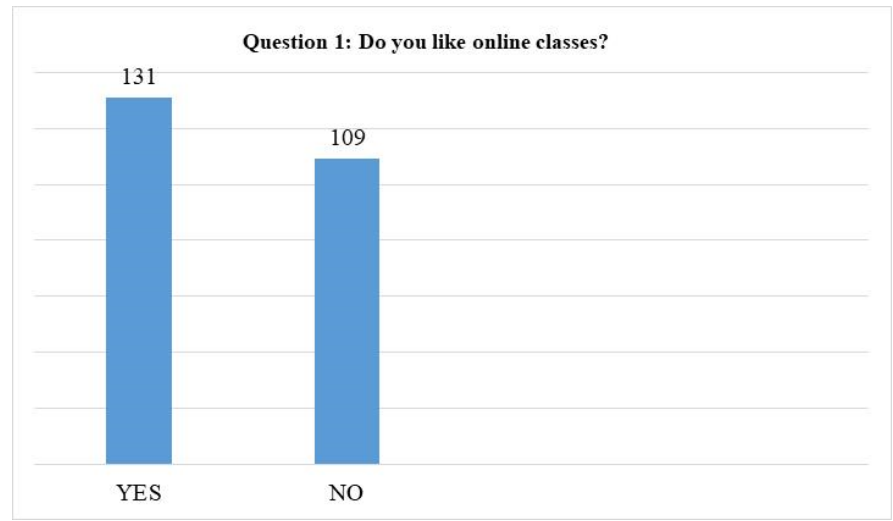

Figure 1: Distribution of the respondents regarding like or dislike online classes

A majority of the respondents (131 students) reported that they like online classes while 109 students dislike online classes. In the pandemic of Covid-19 students don't want to waste their time and love to continue their education. As this virus is spreading from person to person so majority of the respondents understands the sensitivity of the condition and prefer online classes.

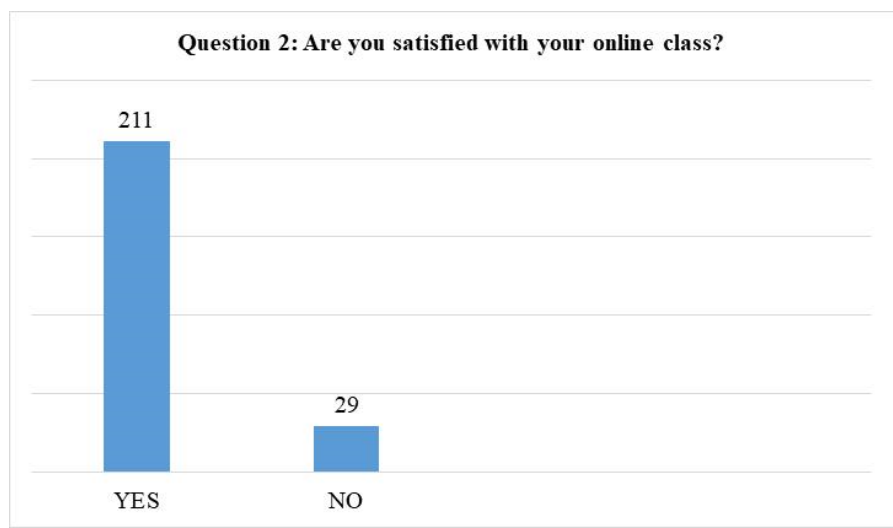

Figure 2: Distribution of the respondents regarding satisfaction with online classes

A majority of the respondents (211 students) were satisfied with their online classes while 29 students were not satisfied with their online classes. Students are little bit confuse because they don't have any 
experience of digital learning. As time passing the satisfaction level regarding online classes is increasing.

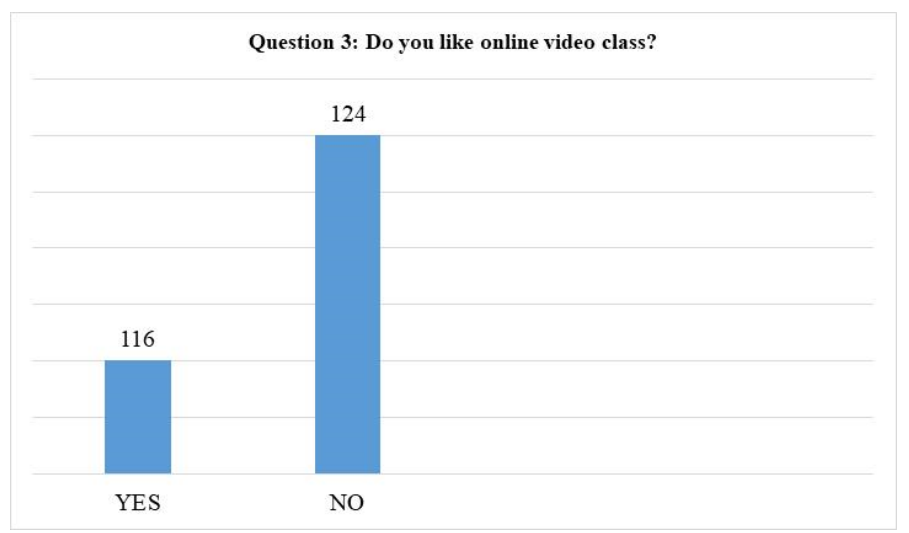

Figure 3: Distribution of the respondents regarding like online video class

A majority of the respondents (124 students) reported that they don't like their online video classes while 116 respondents like online video classes. Here is a reason of disliking video classes that is video recording facility. Female students are not feeling comfortable with video class while audio is more feasible for them. They argue that class fellows can misuse their videos. Another reason that is reported by few female students is related to their religious values. They have opinion that their families don't like video classes because male fellows are also watching them and can make hidden pictures etc.

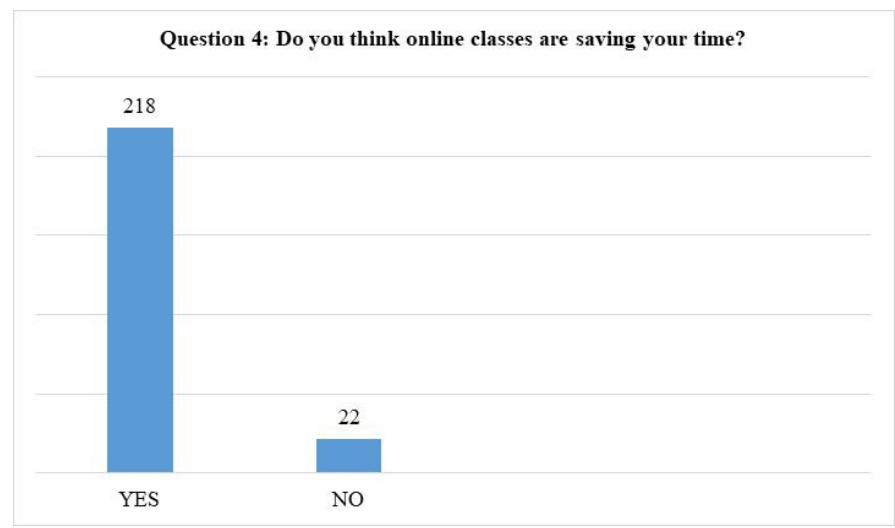

Figure 4: Distribution of the respondents regarding online classes are saving their time

A majority of the respondents (218 students) reported that their online classes are saving their time while 22 students disagreed with the statement. Students are taking online classes as beneficial in this Covid-19 pandemic. Those who dislike online classes said that they are missing their traditional classes and love to enjoy class environment. They also have opinion that online classes are boring as compared to traditional classes. They are unable to interact freely with their fellows and tutor. 


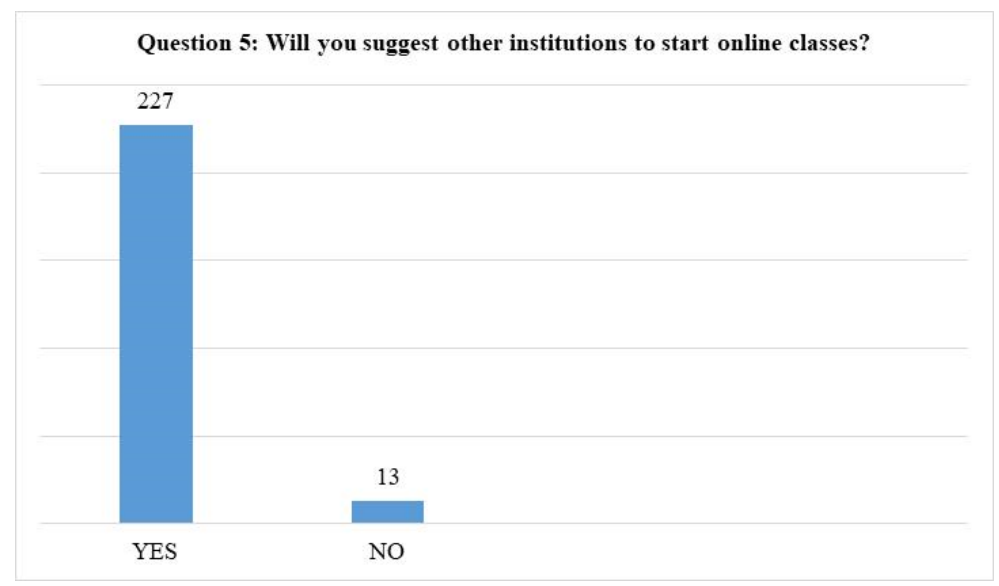

Figure 5: Distribution of the respondents regarding suggestion of online classes to other institutions

A majority of the respondents (227 students) stated that they used to suggest other institutions to start online classes because this is the only effective solution of continuing education in current condition. 13 students reported that they are not suggesting other institutions to start online classes because they are not as effective as traditional classes.

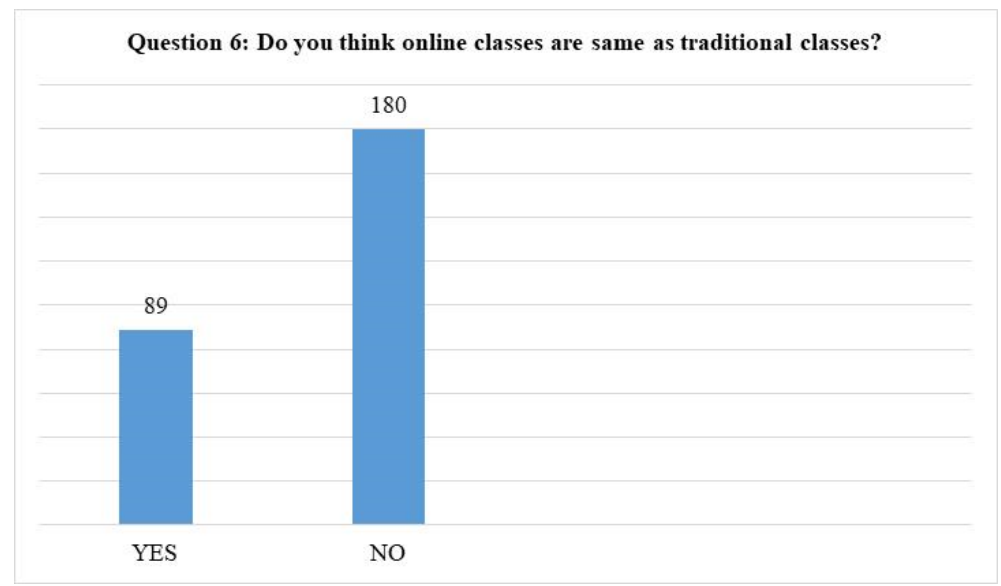

Figure 6: Distribution of the respondents regarding their opinion that online classes are same as traditional classes

A majority of the respondents (151 students) have opinion that online classes are not same as traditional classes while 89 students agreed with the statement. Students were used to attend traditional classes but this new trend of online classes takes time to achieve status same as traditional classes. 


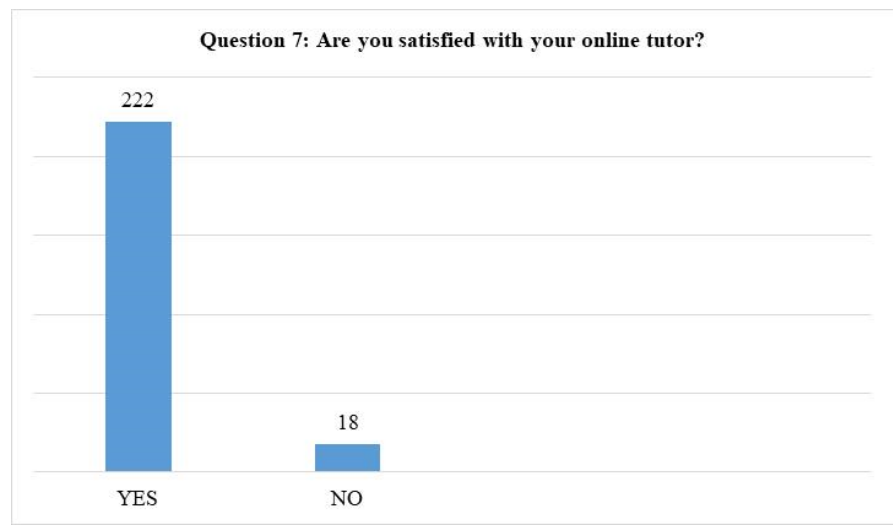

Figure 7: Distribution of the respondents regarding their satisfaction with tutor

A majority of the respondents (222 students) were satisfied with their tutor of online classes. In fact tutors needs training of online classes as well because they are not habitual of these classes. Online teaching is different from traditional teaching. In online classes, teachers have to prepare lecture slides before lecture date because they can't deliver efficiently without slides. Students have to download lecture slides before lecture to understand in a better way. As in traditional class students used to open books during lectures same as they have to go through slides before online lecture. Those teachers who are delivering online lectures have to understand the sensitivity of the condition because now students are already depressed because of lockdown in Pakistan. Students are expecting more from teachers. Teachers must have to adopt lenient techniques to deliver successfully. At the same time there is need to motivate teachers by adopting different motivational strategies for effective service delivery (Ekundayo and Ayodele, 2019).

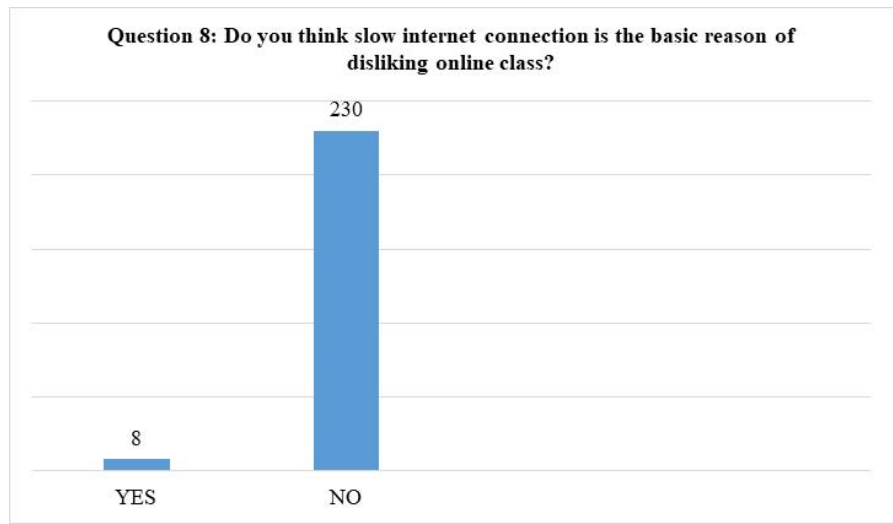

Figure 8: Distribution of the respondents regarding disliking online classes because of slow internet connection

A majority of the respondents (232 students) have opinion that slow internet connection is not the reason of disliking online classes. A few respondents (8 students) reported internet problems because they can't afford internet facility or they are living in slum or rural areas. In Pakistan a lot of slum or rural areas don't have strong internet connection facility. A number of students have to travel to another area where they can find strong internet connection to attend their online class. 


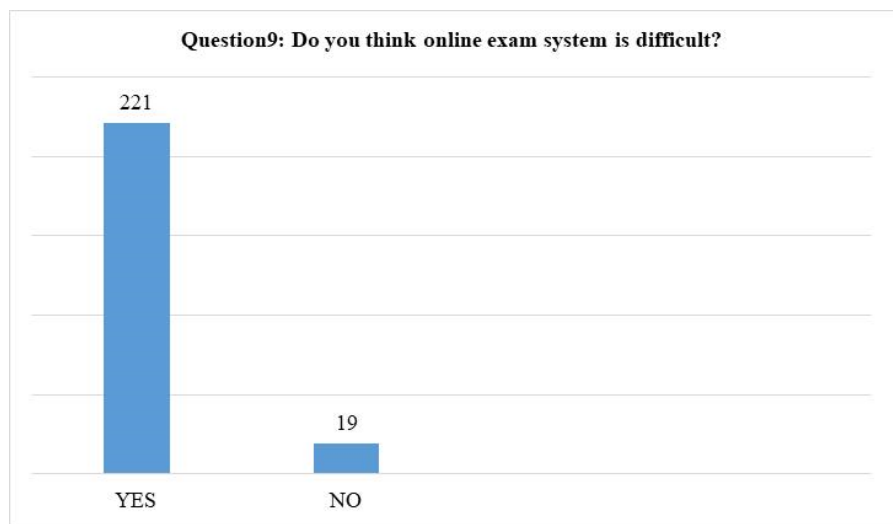

Figure 9: Distribution of the respondents regarding their opinion about online exams

A majority of the respondents (221 students) reported that online exams are difficult as compared to traditional exams system. The reason behind is they don't have previous experience of online exams. As well as they don't have strong stills to use laptops or to solve online papers. A few students reported that they don't have fast typing speed to handle online exams.

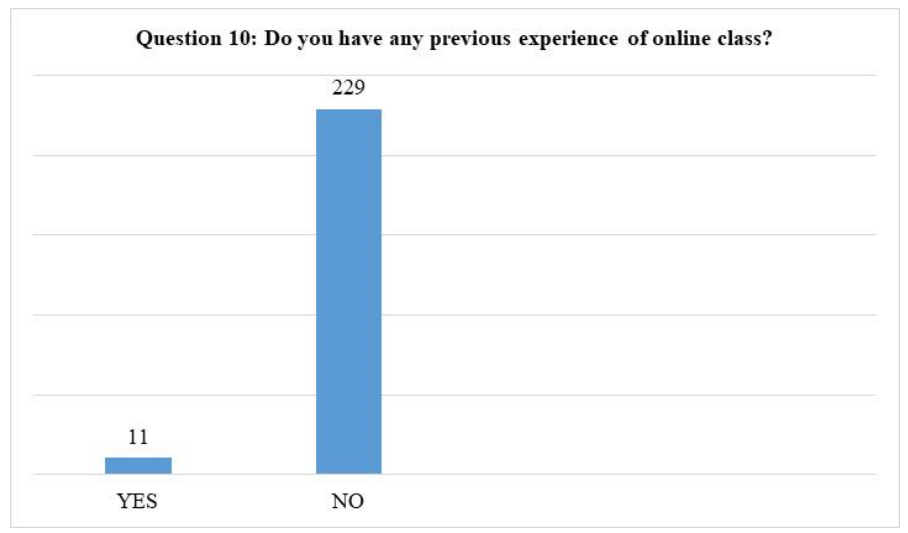

Figure 10: Distribution of the respondents regarding previous experience of online classes

A majority of the respondents (229 students) don't have any previous experience of online classes. This is the basic reason of disliking online classes. Everything in life that we are doing first time is difficult to start but as we are doing it we are getting comfortable with it day by day. Same as online classes are new for majority of the students but with the passage of time students will ease with it.

\section{Conclusion}

Covid-19 totally changed the life style of the people in the whole world. Pakistan is undergoing with the same situation. Because of Covid-19 all educational institutions in Pakistan are closed and online teaching system is introduced. Every new habit takes time to be permanent. Students are feeling pressure of online classes. Students were not habitual of digital learning system. If we have to go with the situation then we have to adopt new technologies as these are the requirements of the present day. This survey was conducted to analyze the situation of online classes whether students are 
accepting it or not. For this purpose 240 students were selected who were taking online classes in Lahore, Pakistan. This survey showed that a majority of the students accepted digital learning system. Students are trying to be comfortable with online classes. Education is very important to get skills and to become active citizen of any society. So, digital education has been started in many of the educational institutions in Pakistan to utilize time efficiently.

\section{Recommendations}

1- There is need to spread awareness of the importance of online classes.

2- Teachers should adopt new methods of teaching.

3- Government should spread awareness of online education through media.

4- Government should provide free of cost internet facility to all the teachers and students to carry on their educational activities.

5- Educational institutions should introduce digital libraries to the teachers and students.

6- Teachers should adopt soft teaching techniques to ease students in difficult circumstances like Covid-19.

\section{References}

Bai, Y., Yao, L., Wei, T., Tian, F., Jin, D. Y., Chen, L., \& Wang, M. (2020). Presumed asymptomatic carrier transmission of COVID-19. Jama, 323(14), 1406-1407.

Bukodi, E., \& Goldthorpe, J. H. (2013). Decomposing 'social origins': The effects of parents' class, status, and education on the educational attainment of their children. European sociological review, 29(5), 1024-1039.

Ekundayo, H. T., \& Ayodele, V. O. (2019). How Best to Motivate Lecturers for Better Service Delivery in Nigerian Universities. Mediterranean Journal of Social Sciences, 10(6), 115-115.

Galusha, J. M. (1998). Barriers to learning in distance education.

Grant, N. (2008, March). On the usage of social networking software technologies in distance learning education. In Society for information technology \& teacher education international conference (pp. 3755-3759). Association for the Advancement of Computing in Education (AACE).

HEC (2020) https://www.hec.gov.pk/english/HECAnnouncements/Documents/nCoVirus/Covid-19-PolicyGuidance-No.5-Online\%2oReadiness.pdf

Ichou, M. (2014). Who they were there: Immigrants' educational selectivity and their children's educational attainment. European sociological review, 30(6), 750-765.

Johansson, B., FOGELBERG-DAHM, M. A. R. I. E., \& Wadensten, B. (2010). Evidence-based practice: the importance of education and leadership. Journal of nursing management, 18(1), 70-77.

Moller, L., \& Soles, C. (2001). Myers Briggs type preferences in distance learning education. International Journal of Educational Technology, 2(2).

Palloff, R., \& Pratt, L. (1999). Building Learning Communities in Cyberspace. San Francisco: Jossey-Bass, Inc., pp. $8,18,24,32-38,166$.

Rud, I., Van Klaveren, C., Groot, W., \& van den Brink, H. M. (2014). The externalities of crime: The effect of criminal involvement of parents on the educational attainment of their children. Economics of Education Review, 38, 89-103.

Shen, R., Tang, Y., \& Zhang, T. (2001, October). The intelligent assessment system in Web-based distance learning education. In 31st Annual Frontiers in Education Conference. Impact on Engineering and Science Education. Conference Proceedings (Cat. No. o1CH37193) (Vol. 1, pp. TIF-7). IEEE.

Spera, C., Wentzel, K. R., \& Matto, H. C. (2009). Parental aspirations for their children's educational attainment: Relations to ethnicity, parental education, children's academic performance, and parental perceptions of school climate. Journal of youth and adolescence, $38(8), 1140-1152$.

WHO

https://www.who.int/emergencies/diseases/novel-coronavirus2019?gclid=EAIaIQobChMIgIOXxKjT6QIVzbLVChıNJwTiEAAYASAAEgJghvD_BwE 